\title{
Research Article \\ EVALUATION OF TYROSINASE PRODUCING INDIGENOUS BACTERIAL STRAINS WITH REFERENCE TO THEIR EFFICACY IN L-DOPA PRODUCTION
}

\author{
SHARMA ANJANA*1, VYAS PRASHANSA ${ }^{1}$ AND REHMAN MEENAL BUDHOLIA ${ }^{2}$ \\ ${ }^{1}$ Bacteriology Laboratory, Department of P. G. Studies and Research in Biological Science, Rani Durgavati University, Jabalpur, 482001, Madhya Pradesh, India \\ 2Department of Botany, Mata Gujir Women's College, Jabalpur, Madhya Pradesh, 482001, India \\ *Corresponding Author: Email - anjo01999@gmail.com
}

Received: May 14, 2018; Revised: May 23, 2018; Accepted: May 24, 2018; Published: May 30, 2018

\begin{abstract}
The present study is focussed on isolation and screening of tyrosinase enzyme produced by bacterial isolates and its application in the production of L-Dopa. L- Dopa is an amino acid which is used as a drug for the treatment of Parkinson's disease. 112 bacterial isolates have been screened which were collected from soil of different gardens of Jabalpur, Madhya Pradesh. Tyrosinase activity of all bacterial isolates was determined qualitatively and quantitatively. The primary screening of all the isolates for Tyrosinase production was carried on Tyrosine agar medium. Among them 21 isolates showed brown pigmented colonies indicating Tyrosinase activity. Secondary screening was done on the basis of extracellular enzyme activity. Based on the result of secondary screening, out of 21 isolates 5 were reported as potential Tyrosinase producers which were further checked for L-Dopa production. On the basis of morphological, cultural and biochemical characteristics the potent L-Dopa producing bacterial isolate was identified as Pseudomanas sp which could be a promising source for the production of L-Dopa.
\end{abstract}

Keywords- Tyrosinase, L-Dopa, Drug, L- Tyrosine, Soil, identification

Citation: Sharma Anjana, et al., (2018) Evaluation of Tyrosinase Producing Indigenous Bacterial Strains with Reference to their Efficacy in L-Dopa Production. International Journal of Microbiology Research, ISSN: 0975-5276 \& E-ISSN: 0975-9174, Volume 10, Issue 5, pp.-1202-1204.

Copyright: Copyright@2018 Sharma Anjana, et al., This is an open-access article distributed under the terms of the Creative Commons Attribution License, which permits unrestricted use, distribution and reproduction in any medium, provided the original author and source are credited.

\section{Introduction}

L-Dopa (3,4 dihydroxyphenylalanine) is an amino acid which is used as a drug for the treatment of Parkinson's disease [1]. Parkinson's disease affects approximately 1.5 million people worldwide and the cost of the treatment is more than 14 billion a year according to research published in Movement disorder 2014 [2]. This disease is caused due to insufficiency of the neurotransmitter dopamine [3]. Mosanto first developed the asymmetric hydrogenation method for the synthesis of L-Dopa which showed many limitations such as poor conversion rate, low enantioselectivity and high production cost [4]. In contrast biotechnological approaches have been explored as potential alternative not only for improving the poor conversion rate but also for economizing the process. L- Dopa is biotechnologically synthesized from L- Tyrosine by one step reaction catalyzed by tyrosinase [5]. Tyrosinase (1.14.18.1) is a copper containing enzyme which is widely distributed in plants, animals and microorganisms. This enzyme has both monophenolase and diphenolase activity and responsible for the biosynthesis of melanin. It has been produced from various sources such as Escherichia intermedia [6], Bacillus thuringiensis [7], Banana [8], Aspergillus oryzae [9], Portulaca grandiflora [10], Yarrowia Iypolytica [11], Acremonium rutilum [12], Brevundimonas sp [13] and Bacillus sp JPJ [1] and Hypericum lariciforium juss [14] Although, it has been observed that very few attempts have been made to produce L-Dopa using bacterial sources. Therefore, the present study is undertaken to isolate and explore L-Dopa producing bacteria present in the soil.

\section{Materials and Methods \\ Chemicals}

L-tyrosine, Tryptone, L-Dopa and all other chemicals were procured from Himedia, India. All chemicals were of the highest purity available and of analytical grade.

\section{Isolation of bacterial isolates}

Soil samples were collected from different gardens of Jabalpur (M.P) and all samples were enriched in Tyrosine broth medium containing (Yeast extract $0.3 \mathrm{~g} /$, Peptone $0.5 \mathrm{~g} / \mathrm{l}, \mathrm{NaCl} 0.5 \mathrm{~g} / \mathrm{l}$ and L-Tyrosine $1 \mathrm{~g} / \mathrm{l}) \mathrm{pH} 7$ at $37^{\circ} \mathrm{C}$ and $120 \mathrm{rpm}$ for 24 h. Thereafter enriched samples were serially diluted, plated and incubated in incubator at $37^{\circ} \mathrm{C}$ for 24 hours. All tyrosinase producing isolates were maintained on nutrient agar slants and stored at $4^{\circ} \mathrm{C}$ for further use.

\section{Primary screening}

Primary screening of all the bacterial isolates was carried on tyrosine agar medium containing ( $\mathrm{NaCl} 5 \mathrm{~g} /$, Beef Extract $3 \mathrm{~g} / /$, Peptone $5 \mathrm{~g} / \mathrm{l}$, Agar 20g/l) pH 7.0 supplemented with $1 \mathrm{~g} / \mathrm{L}$ - Tyrosine. All the isolates were streaked on to tyrosine agar medium and incubated in incubator at $37^{\circ} \mathrm{C}$ for 24 hours [1].

\section{Secondary screening \\ Preparation of crude enzyme extract}

24hour old culture was inoculated on to sterilized broth containing (Tryptone $4 \mathrm{~g} / \mathrm{l}$, Beef extract $0.5 \mathrm{~g} / \mathrm{l}$, and L-Tyrosine $1 \mathrm{~g} / \mathrm{l}) \mathrm{pH}$ 7and incubated at $37^{\circ} \mathrm{C}$ in orbital shaker incubator at $120 \mathrm{rpm}$ for 24 hours. After the growth of $16-18$ hour having absorbance 0.75 were harvested by centrifugation at $8000 \mathrm{rpm}$ for 15 minutes at $4^{\circ} \mathrm{C}$ and the cell free supernatant was used further for Tyrosinase activity and Protein content.

\section{Tyrosinase activity}

Tyrosinase activity of all the selected isolates was done by following the method of [10]. 

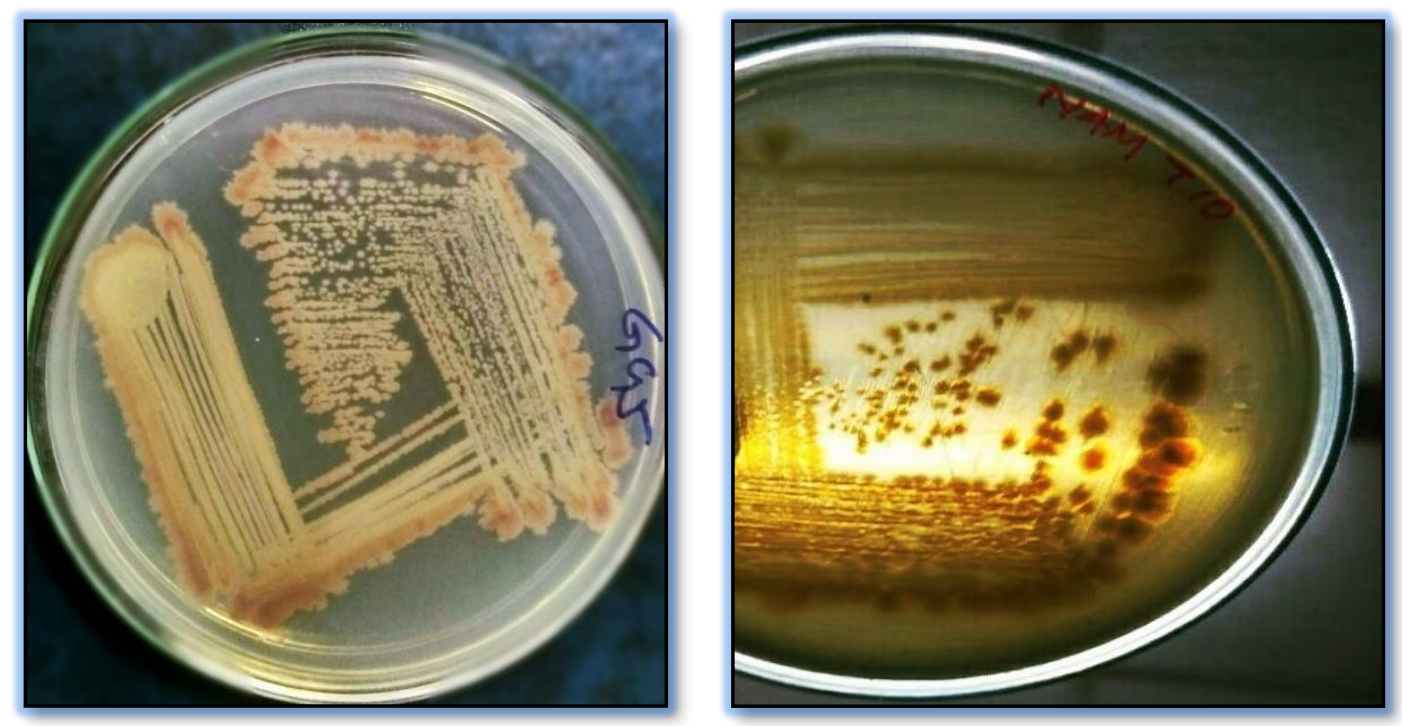

Fig-1 Primary screening of Tyrosinase producing Bacterial isolates

The final assay concentration in $3 \mathrm{ml}$ reaction mixture contained $1 \mathrm{ml}$ of $50 \mathrm{mM}$ Pottasium Phosphate buffer (pH 7.4), $1 \mathrm{ml}$ of L-tyrosine, $0.8 \mathrm{ml}$ of distilled water, $0.1 \mathrm{ml} \mathrm{L}$-ascorbic acid and $0.1 \mathrm{ml}$ of culture supernatant of Tyrosinase positive isolates. The reaction mixture without culture supernatant was used as blank. Tyrosinase activity was estimated at A280 nm for 10 minutes using UV-Vis spectrophotometer. One unit of tyrosinase activity was equal to $A 280 \mathrm{~nm}$ of $0.001 / \mathrm{min}$ at $\mathrm{pH} 7.4$ at $25^{\circ} \mathrm{C}$ in $3 \mathrm{ml}$ reaction mixture containing l-tyrosine. Protein content was estimated using Lowry's method [15]. The enzyme activity can be calculated by using following formula:

Units of enzyme/ml

$\Delta \mathrm{A} 280 \mathrm{~nm} / \mathrm{min}$ Test $-\Delta \mathrm{A} 280 \mathrm{~nm} / \mathrm{min}$ Blank (df)

\section{L-Dopa assay}

The L-dopa assay was determined according to Arnow's method [16]. $1 \mathrm{ml}$ of supernatant was added with $1 \mathrm{ml}$ of $0.5 \mathrm{NHCL}, 1 \mathrm{ml}$ of nitrite molybdate reagent and $1 \mathrm{ml}$ of $1 \mathrm{~N} \mathrm{NAOH}$ then final volume was adjusted to $5 \mathrm{ml}$ by distilled water. The absorbance was measured at $530 \mathrm{~nm}$ using UV- Vis spectrophotometer and concentration of L- Dopa was determined from Arnow standard curve of L- dopa. All the experiments were carried out in triplicates.

\section{$Y=1.892 x+0.009 / R 2=0.996$}

\section{Identification of Bacterial Isolate}

L-Dopa producing bacterial isolate was characterized on the basis of Morphological, Cultural and Biochemical following Bergeys Manual of Systematic Bacteriology [17] and Probabilistic Identification of Bacteria (PIB) [18] computer kit.

\section{Results and Discussion}

Soil is a source of indigenous bacteria therefore, in this study, for the isolation of tyrosinase producing bacterial isolates we have collected soil samples from different gardens of Jabalpur (M.P) and enriched in tyrosine broth for $24 \mathrm{~h}$. Enriched samples were serially diluted and inoculated in a plate containing media, 112 bacterial isolates were isolated. These isolates were further purified in Nutrient agar medium. Thereafter, bacterial isolates were primarily screened for tyrosinase production by using tyrosine agar medium. Out of 112 bacterial isolates 21 isolates showed brown pigmentation indicating tyrosinase activity. Likewise, Raval, et al., also isolated 10 isolates of Actinomycetes and used tyrosine agar medium for primary screening of tyrosinase enzyme and also reported that Formation of brown color was mainly due to melanin [19]. After primary screening, these isolates were further checked for extracellular tyrosinase activity. Among 21, 5 isolates i.e., TG10, TG7, GG5, GG6, BP8 showed maximum extracellular tyrosinase activity as shown in [Table-2].

\section{L-Dopa assay}

Tyrosinase (1.14.18.1) is a copper containing enzyme and has two catalytic activities. It catalyzes orthohydroxylation of monophenols to diphenols by cresolase activity. It also successively oxidizes diphenols to quinone by catecholase activity [20]. Accordingly, based on tyrosinase activity L-Dopa can be produced by 0 - hydroxylation of $L$ - Tyrosine by cresolase activity [21] therefore in the present investigation bacterial isolates which exhibited maximum tyrosinase activity were further assayed for L-Dopa production. Nitrite molybdate reagent when added to cell free supernatant gives the formation of yellow colour. Further addition of $1 \mathrm{~N} \mathrm{NaOH}$ resulted in the formation of red colour similar to the one formed at standard L-Dopa. Isolate TG10 produces $0.0385 \mathrm{mg} / \mathrm{ml}$, TG7 produces $0.0367 \mathrm{mg} / \mathrm{ml}$ and GG5 produces $0.0372 \mathrm{mg} / \mathrm{ml}$ L-Dopa after $18 \mathrm{~h}$ of incubation as shown in [Table-3]. Previously, Surwase, et al., For the first time reported that the bacterial strain has the ability to utilize L-Tyrosine for producing L-Dopa. They isolated Bacillus sp. JPJ \& Brevundimonas sp. SGJ having the ability to convert LTyrosine to L-Dopa from soil samples which can be more favorable for industrial fermentation than plant, fungi and yeast. From the above results, bacterial isolate which have the potential to produce I-Dopa was identified as Pseudomonas sp. on the basis of morphological and biochemical characteristics [Table-4].

Table-1 Qualitative Screening of Tyrosinase Producing Bacterial Isolates.

\begin{tabular}{|c|c|c|}
\hline S.No & Code & Brown Pigmented Colonies \\
\hline 1 & TG2 & + \\
\hline 2 & TG7 & + \\
\hline 3 & TG8 & + \\
\hline 4 & TG10 & + \\
\hline 5 & YM6 & - \\
\hline 6 & YM5 & - \\
\hline 7 & YM1 & + \\
\hline 8 & GG7 & + \\
\hline 9 & GG5 & + \\
\hline 10 & BP8 & + \\
\hline 11 & BP11 & - \\
\hline 12 & BP9 & - \\
\hline 13 & BP12 & + \\
\hline 14 & BP13 & + \\
\hline 15 & GG1 & + \\
\hline 16 & BP10 & + \\
\hline 17 & BP1 & + \\
\hline 18 & BP2 & + \\
\hline 19 & GG3 & + \\
\hline 20 & GG6 & + \\
\hline 21 & GG4 & + \\
\hline
\end{tabular}


Table-2 Quantitative Screening of Tyrosinase Producing Bacterial Isolates

\begin{tabular}{|c|c|c|c|}
\hline Code & $\begin{array}{c}\text { Enzyme Activity } \\
(\text { IU/ml) }\end{array}$ & $\begin{array}{c}\text { Protein Content } \\
(\mathrm{mg} / \mathrm{ml})\end{array}$ & $\begin{array}{c}\text { Specific Activity } \\
(\text { IU/mg) }\end{array}$ \\
\hline TG2 & 2.88 & 1.95 & 1.47 \\
\hline TG7 & 4.53 & 1.77 & 2.55 \\
\hline TG8 & 5.3 & 2.41 & 2.19 \\
\hline TG10 & 11.89 & 1.96 & 6.06 \\
\hline YM6 & 1.47 & 2.3 & 0.639 \\
\hline YM5 & 1.5 & 2.28 & 0.657 \\
\hline YM1 & 2.54 & 2.3 & 1.1 \\
\hline GG7 & 6.95 & 2.87 & 2.42 \\
\hline GG5 & 8.01 & 2.8 & 2.86 \\
\hline BP8 & 7.89 & 2.77 & 2.84 \\
\hline BP11 & 2.34 & 2.84 & 0.823 \\
\hline BP9 & 2.78 & 2.8 & 0.992 \\
\hline BP12 & 2.98 & 2.87 & 1.03 \\
\hline BP13 & 2.99 & 2.87 & 1.04 \\
\hline GG1 & 3.08 & 2.95 & 1.04 \\
\hline BP10 & 2.59 & 2.99 & 0.866 \\
\hline BP1 & 3.51 & 3.04 & 1.15 \\
\hline BP2 & 4.32 & 2.9 & 1.48 \\
\hline GG3 & 3.1 & 2.75 & 1.12 \\
\hline GG6 & 4.1 & 2.89 & 1.41 \\
\hline GG4 & 3.08 & 3.03 & 1.01 \\
\hline
\end{tabular}

Table-3 Production of L-Dopa by maximum Tyrosinase producing Bacterial Isolates

\begin{tabular}{|r|c|c|}
\hline S.No & Isolate Code & L-Dopa $(\mathrm{mg} / \mathrm{ml})$ \\
\hline 1 & GG5 & 0.0372 \\
\hline 2 & GG6 & 0.0343 \\
\hline 3 & TG10 & 0.0385 \\
\hline 4 & TG7 & 0.0375 \\
\hline 5 & BP8 & 0.0252 \\
\hline
\end{tabular}

\section{Conclusion}

The indigenous Psuedomanas sp. Isolated from soil was found to be a potent LDopa producer. For better production of L-Dopa, further work on the optimization, purification and characterization of the tyrosinase enzyme is in progress prior to scale up studies.

Application of research: L-Dopa is a compound of clinical importance, which is produced by the enzyme Tyrosinase. Further, study of an enzyme may enable in developing a simpler and feasible bacterial system for achieving higher yield of $L$ Dopa.

Research Category: Isolation and screening of tyrosinase enzyme

\section{Abbreviations:}

L-Dopa- 3,4 dihydroxyphenylalanine

$\mathrm{NaOH}$ - Sodium Hydroxide

$\mathrm{NaCl}$ - Sodium Chloride

HCL- Hydrochloric acid df- dilution factor

Acknowledgement / Funding: Authors are thankful to Department of P. G. Studies and Research in Biological Science, Rani Durgavati University, Jabalpur, 482001, Madhya Pradesh, India

*Research Guide or Chairperson of research: Prof Anjana Sharma University: Rani Durgavati University, Jabalpur, 482001, Madhya Pradesh, India Research project name or number: Nil

\section{Author Contributions: All author equally contributed}

Author statement: All authors read, reviewed, agree and approved the final manuscript

\section{Conflict of Interest: None declared}

Ethical approval: This article does not contain any studies with human participants or animals performed by any of the authors.

\section{References}

[1] Surwase S., Patil S., Onkar A., Jadhav J. (2012) Appl Biochem Biotechnol., 167,1015-1028.

[2] Stocchi F., Martin P., Reichmann H. (2014) Movem Disor., 12-17.

[3] Kofman O. (1971) Can Med Assoc J., 104,483-487.

[4] Min K., Park K., Park D., Yoo Y. (2015) Appl microbiol biotechnol., 99, 575- 584.

[5] Shushter V., Fishman A. (2009) J Mol Microbiol Biotechnol., 17,188200.

[6] Para G.M. \& Baratti J.C. (1984) Appl Environ Microbiol.,48,1256-1258.

[7] Liu N., Zhang T., Wang Y.J., Hwang Y.P., Ou J.H., Shen P. (2004) Lett Appl Microbiol., 39,407-412.

[8] Bapat V., Suprasanna P., Ganapathi T., Rao P. (2000) Pharm Biol., 38,271-273.

[9] Ali S., Schultz I., Haq I. (2006) BMC Biotechnol., 7, 50-57.

[10] Rani N., Joy B., Abraham E. (2007) Pharm Biol., 45,48-53.

[11] Ali S., Schultz I., Haq I. (2007) BMC Biotechnol., 7(1)-50.

[12] Krishnaveni R., Rathod V., Thakur M., Neelgund Y. (2009) Curr Microbiol., 58,122-128.

[13] Surwase S., Jadhav J. (2010) Appl Biochem Biotechnol., 41,495-506.

[14] Yanymee N.G.Q., Seung H.H., Wang Z., Soon S.L. (2017) Molecules, 22,402

[15] Lowry O.H., Rosebrough N.J., Farr A.L., Randell R.J. (1951) J Biol Chem., 193,265-275.

[16] Arnow L.E. (1937) J Biochem., 118, 531-537.

[17] Kreig R.N. and Holt J.G. (1984) Vol.1 Williams and Wilkins Co, Baltimore, USA.

[18] Bryant T.N. (2003) PIB computer kit, Medical statistics and computing, University of Southampton, SO94XYUK.

[19] Raval K., Vaswani P., Majumder D. (2012) Interna Jour of Scienti and Resear Pub., 2,2250-3153.

[20] Min K., Yoo Y.J. (2009) Talanta, 80(2), 99, 1007-1011.

[21] Min K., Park D.H., Yoo Y.J. (2010) J Biotechnol., 146,( 1-2), 40-44.

Table-4 Morphological and Biochemical features of potent L-DOPA producing bacteria isolated from garden soil.

\begin{tabular}{|c|c|c|c|c|c|c|c|c|c|c|c|c|c|c|c|c|c|c|c|c|c|c|}
\hline Isolate & Morphology & Motility & A & B & C & D & $E$ & $\mathrm{~F}$ & G & $\mathrm{H}$ & I & $\mathrm{J}$ & $\mathrm{K}$ & $\mathrm{L}$ & $M$ & $\mathrm{~N}$ & 0 & $P$ & Q & $\mathrm{R}$ & $S$ & Organism \\
\hline TG10 & $\begin{array}{l}\text { Gram } \\
\text { negative } \\
\text { bacilli }\end{array}$ & + & - & - & - & + & - & - & - & - & - & - & - & + & + & - & - & + & - & + & - & Psuedomonas sp. \\
\hline
\end{tabular}

A-Indole, B-Methyl Red, C-Voges Proskauer, D-Citrate Utilization, E-Sucrose Fermentation, F-Lactose, G-Sucrose, H- Mannitol, I- Gas, J-Hydrogen Sulphide Production, KOxidase, L-Catalase, M-Starch Hydrolysis, N-Urease, O-Nitrate Reduction, P- Non Lactose Fermenters, Q-Lactose Fermenters, R-Ornithine Decarboxylse, S-Arginine Decarboxylase 